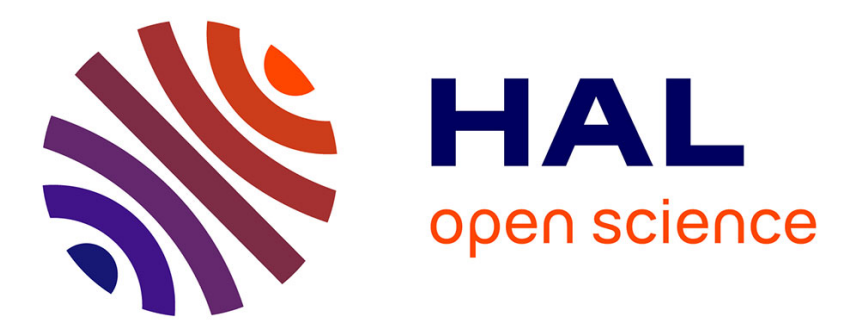

\title{
Atomic scale structure of amorphous aluminum oxyhydroxide, oxide and oxycarbide films probed by very high field $27 \mathrm{Al}$ nuclear magnetic resonance \\ Loïc Baggetto, Vincent Sarou-Kanian, Pierre Florian, Alain Gleizes, Dominique Massiot, Constantin Vahlas
}

\section{To cite this version:}

Loïc Baggetto, Vincent Sarou-Kanian, Pierre Florian, Alain Gleizes, Dominique Massiot, et al.. Atomic scale structure of amorphous aluminum oxyhydroxide, oxide and oxycarbide films probed by very high field 27Al nuclear magnetic resonance. Physical Chemistry Chemical Physics, 2017, 19 (11), pp.8101-8110. 10.1039/c6cp07937g · hal-01524914

\author{
HAL Id: hal-01524914 \\ https://hal.science/hal-01524914
}

Submitted on 19 May 2017

HAL is a multi-disciplinary open access archive for the deposit and dissemination of scientific research documents, whether they are published or not. The documents may come from teaching and research institutions in France or abroad, or from public or private research centers.
L'archive ouverte pluridisciplinaire HAL, est destinée au dépôt et à la diffusion de documents scientifiques de niveau recherche, publiés ou non, émanant des établissements d'enseignement et de recherche français ou étrangers, des laboratoires publics ou privés. 


\section{OATAO}

Open Archive Toulouse Archive Ouverte

\section{Open Archive TOULOUSE Archive Ouverte (OATAO)}

OATAO is an open access repository that collects the work of Toulouse researchers and makes it freely available over the web where possible.

This is an author-deposited version published in : http://oatao.univ-toulouse.fr/ Eprints ID : 17818

To link to this article : DOI:10.1039/c6cp07937g

URL : http://dx.doi.org/10.1039/c6cp07937g

To cite this version : Baggetto, Loïc and Sarou-Kanian, Vincent and Florian, Pierre and Gleizes, Alain and Massiot, Dominique and Vahlas, Constantin Atomic scale structure of amorphous aluminum oxyhydroxide, oxide and oxycarbide films probed by very high field $27 \mathrm{Al}$ nuclear magnetic resonance. (2017) Physical Chemistry Chemical Physics, vol. 19 (n 11). pp. 8101-8110. ISSN 1463-9076

Any correspondence concerning this service should be sent to the repository administrator: staff-oatao@,listes-diff.inp-toulouse.fr 


\title{
Atomic scale structure of amorphous aluminum oxyhydroxide, oxide and oxycarbide films probed by very high field ${ }^{27} \mathrm{Al}$ nuclear magnetic resonance $\dagger$
}

\author{
L. Baggetto, ${ }^{a}$ V. Sarou-Kanian, ${ }^{\star b c}$ P. Florian, ${ }^{\text {bc }}$ A. N. Gleizes, ${ }^{a}$ D. Massiot ${ }^{\text {bc }}$ and \\ C. Vahlas ${ }^{* a}$
}

\begin{abstract}
The atomic scale structure of aluminum in amorphous alumina films processed by direct liquid injection chemical vapor deposition from aluminum tri-isopropoxide (ATI) and dimethyl isopropoxide (DMAI) is investigated by solid-state ${ }^{27} \mathrm{Al}$ nuclear magnetic resonance (SSNMR) using a very high magnetic field of 20.0 T. This study is performed as a function of the deposition temperature in the range $300-560{ }^{\circ} \mathrm{C}$, $150-450{ }^{\circ} \mathrm{C}$, and $500-700{ }^{\circ} \mathrm{C}$, for the films processed from ATI, DMAI $\left(+\mathrm{H}_{2} \mathrm{O}\right)$, and DMAI $\left(+\mathrm{O}_{2}\right)$, respectively. While the majority of the films are composed of stoichiometric aluminum oxide, other samples are partially or fully hydroxylated at low temperature, or contain carbidic carbon when processed from DMAI above $500{ }^{\circ} \mathrm{C}$. The quantitative analysis of the SSNMR experiments reveals that the local structure of these films is built from $\mathrm{AlO}_{4}, \mathrm{AlO}_{5}, \mathrm{AlO}_{6}$ and $\mathrm{Al}(\mathrm{O}, \mathrm{C})_{4}$ units with minor proportions of the 6-fold aluminum coordination and significant amounts of oxycarbides in the films processed from DMAI $\left(+\mathrm{O}_{2}\right)$. The aluminum coordination distribution as well as the chemical shift distribution indicate that the films processed from DMAI present a higher degree of structural disorder compared to the films processed from ATI. Hydroxylation leads to an increase of the 6 -fold coordination resulting from the trend of $\mathrm{OH}$ groups to integrate into $\mathrm{AlO}_{6}$ units. The evidence of an additional environment in films processed from DMAI $\left(+\mathrm{O}_{2}\right)$ by ${ }^{27} \mathrm{Al}$ SSNMR and first-principle NMR calculations on $\mathrm{Al}_{4} \mathrm{C}_{3}$ and $\mathrm{Al}_{4} \mathrm{O}_{4} \mathrm{C}$ crystal structures supports that carbon is located in $\mathrm{Al}(\mathrm{O}, \mathrm{C})_{4}$ units. The concentration of this coordination environment strongly increases with increasing process temperature from 600 to $700{ }^{\circ} \mathrm{C}$ favoring a highly disordered structure and preventing from crystallizing into $\gamma$-alumina. The obtained results are a valuable guide to the selection of process conditions for the CVD of amorphous alumina films with regard to targeted applications.
\end{abstract}

\section{Introduction}

Aluminum oxide (alumina) is a material of critical importance in modern applications related to microelectronic, electrical, machining and pharmaceutical products. The widespread use of alumina is intimately linked to the functional properties of its various crystallographic polymorphs (corundum, gamma alumina, etc.). ${ }^{1}$ Recently, there has been a surge of interest for the use of alumina films as protective barriers for battery electrode materials, ${ }^{2,3}$ for sensors, ${ }^{4}$ as well as for corrosion and medium temperature $\left(400-600{ }^{\circ} \mathrm{C}\right)$ oxidation protection. ${ }^{5-7}$ Also, the optical properties of alumina films show potential

${ }^{a}$ CIRIMAT-CNRS, 4 allée Emile Monso, BP-44362, 31030 Toulouse Cedex 4, France. E-mail: constantin.vahlas@ensiacet.fr

${ }^{b}$ CEMHTI-CNRS, 1D Avenue de la Recherche Scientifique, 45071 Orléans Cedex 2, France. E-mail: vicent.sarou-kanian@cnrs-orleans.fr

${ }^{c}$ Université d'Orléans, Faculté des Sciences, Avenue du Parc Floral, BP-6749, 45067 Orléans Cedex 2, France

$\dagger$ Electronic supplementary information (ESI) available. See DOI: 10.1039/c6cp07937g for RF transparency, light polarization, and broadband and wide-angle antireflection. ${ }^{8-10}$ The development of materials with such superior properties is strongly linked to the understanding of the atomic structure dictated by the fabrication process. This has been illustrated for amorphous alumina films concerning, for example, the corrosion resistance measured by electrochemical impedance spectroscopy ${ }^{5}$ or their superior mechanical properties (hardness and Young's modulus). ${ }^{11}$ It is therefore crucial to obtain comprehensive insights regarding the influence of a synthesis process on the material atomic structure using powerful characterization methods that unravel the local atomic coordination in the crystalline as well as in the amorphous state. In the latter case, solid-state nuclear magnetic resonance (SSNMR) spectroscopy is a method of choice for probing the local environment of aluminum at the atomic scale.

It is well known that crystalline alumina polymorphs are built upon $\mathrm{AlO}_{4}$ and/or $\mathrm{AlO}_{6}$ polyhedral units. ${ }^{1}$ Amorphous alumina materials, however, adopt more complex structures consisting of a mixture of distorted 4-, 5-, and 6-fold coordinated $\mathrm{Al}$ atoms. ${ }^{12-16}$ 
The existence of the 5-fold environments was well evidenced for thin film systems by Lee et al. who used ${ }^{27} \mathrm{Al}$ solid state nuclear magnetic resonance performed at a "regular" field of 9.4 T. Despite the lack of resolution resulting from the use of a moderate principal magnetic field it was shown that amorphous $\mathrm{Al}_{2} \mathrm{O}_{3}$ films grown by magnetron sputtering and atomic layer deposition (ALD) mainly consist of 4- and 5-fold coordinated aluminum atoms with a low content of 6-fold coordination $\left(\mathrm{AlO}_{4}\right.$ : 56 at\% for sputtering, 54 at\% for ALD; $\mathrm{AlO}_{5}$ : 36 at\% for sputtering, 41 at\% for $\mathrm{ALD} ; \mathrm{AlO}_{6}$ : 7 at\% for sputtering, 5 at $\%$ for ALD were estimated from two-dimensional MQMAS experiments). ${ }^{12,13,15}$ More recently, Sarou-Kanian et al. used very high field $(20.0 \mathrm{~T})$ SSNMR to probe the distributions of aluminum environments and the subtle variations in the local disorder of amorphous alumina thin films prepared by chemical vapor deposition (CVD) from evaporated aluminum tri-isopropoxide (ATI). ${ }^{14}$ Taking advantage of the increased resolution obtained using a $20.0 \mathrm{~T}$ magnet and the possibility of fully simulating the quantitative spectra, it was shown that the deposition temperature $\left(T_{\mathrm{d}}\right)$ critically controls the distribution of the $\mathrm{Al}$ coordination. At $360{ }^{\circ} \mathrm{C}$, the material is composed of a large proportion of $\mathrm{AlO}_{5}$ units (41 at\%) accompanied by significant amounts of $\mathrm{AlO}_{4}$ (33 at\%) and of $\mathrm{AlO}_{6}$ (26 at\%) units. As $T_{\mathrm{d}}$ increases up to about $520{ }^{\circ} \mathrm{C}$, the amount of $\mathrm{AlO}_{5}$ remains rather stable but the amount of $\mathrm{AlO}_{4}\left(\mathrm{AlO}_{6}\right)$ rapidly increases (decreases) to 54 at\% (5 at\%). At higher temperature, parts of the $\mathrm{AlO}_{4}$ and $\mathrm{AlO}_{5}$ units are converted into $\mathrm{AlO}_{6}$ units with the latter concentration approaching 60 at\% at a $T_{\mathrm{d}}$ of $720{ }^{\circ} \mathrm{C}$, which is close to the amount measured in $\gamma-\mathrm{Al}_{2} \mathrm{O}_{3}$. Moreover, the correlation between the local disorder of the amorphous structure and the chemical shift distribution $(\Delta \mathrm{CS})$ led to the conclusion that, for these films, the highest disorder corresponded to the lowest concentration of the $\mathrm{AlO}_{6}$ units. ${ }^{14}$

Alternatively to evaporated ATI, another CVD process to synthesize amorphous alumina films was investigated by using the direct liquid injection (DLI) technology with ATI or dimethylaluminum isopropoxide (DMAI). ${ }^{17-20}$ DMAI is an alumina CVD precursor which has several advantages over ATI such as a significantly higher vapor pressure; it is liquid at room temperature, has a long shelf-life and allows processing of alumina films at $T_{\mathrm{d}}$ as low as $150{ }^{\circ} \mathrm{C} .{ }^{17,18,21}$ Scanning electron microscopy (SEM) and elemental analyses (electron probe micro analysis, EPMA and X-ray photoelectron spectroscopy, XPS) of the amorphous alumina films revealed different microstructures and chemical compositions depending on both the nature of the precursor and the deposition temperature. Firstly, the films obtained from evaporated ATI, and from DLI DMAI present homogeneous and compact structures (Fig. S1, ESI $\dagger$ ). ${ }^{17}$ In contrast, the films obtained from DLI ATI show a columnar growth of agglomerated nodules. ${ }^{20}$ This microstructure contrasts strikingly with the one observed for films grown using evaporated ATI suggesting that the solvent (cyclohexane) used in DLI plays an important role in the nucleation and growth of the film. Secondly, EPMA and XPS analyses showed that the $\mathrm{O} / \mathrm{Al}$ ratio is generally different from the one of stoichiometric alumina $(\mathrm{O} / \mathrm{Al}=1.5)$ over a wide range of temperature. The $\mathrm{O} / \mathrm{Al}$ ratio exceeds 1.5 below $480{ }^{\circ} \mathrm{C}$ using
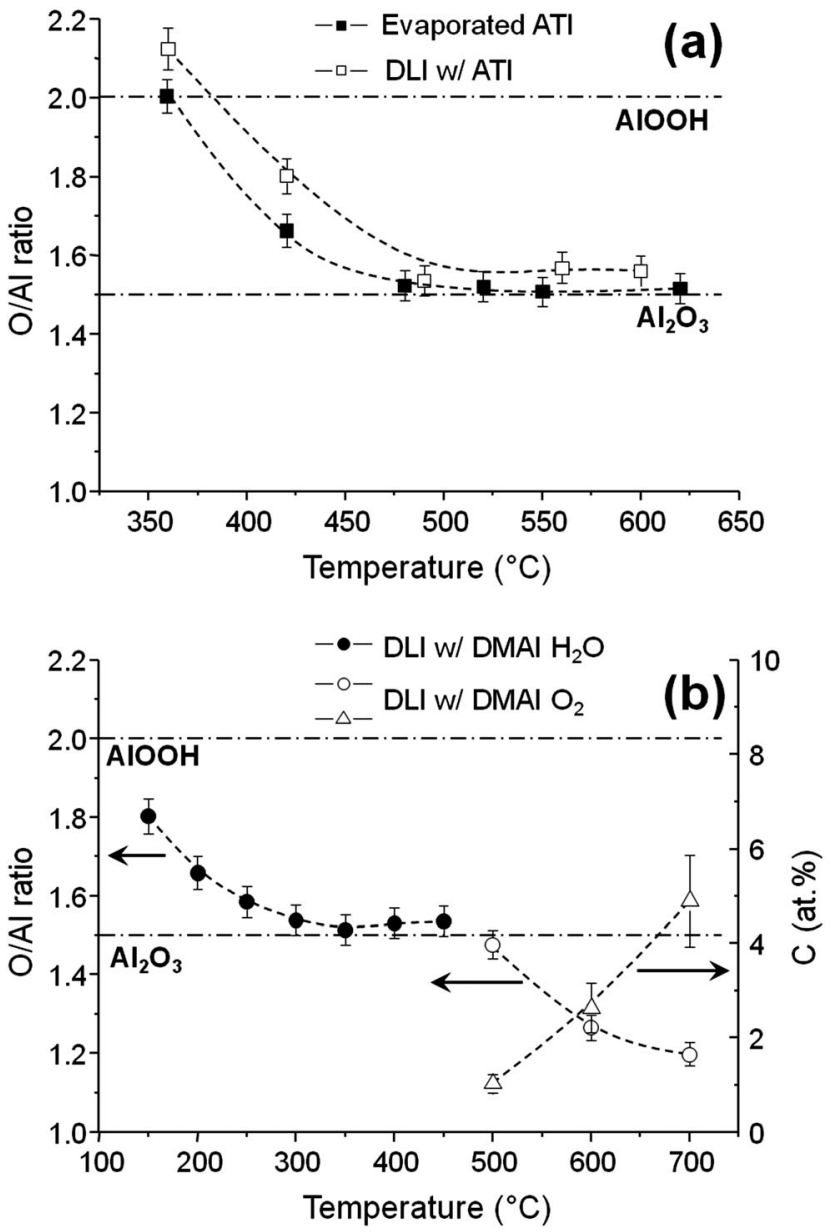

Fig. 1 (a) O/Al atomic ratios measured by EPMA for films processed from evaporated ATI ( $\mathbf{\square})$ DLI ATI ( $\square$ ) as a function of the temperature deposition. (b) O/Al atomic ratios measured by EPMA for films processed from DLI $\left(D M A I+\mathrm{H}_{2} \mathrm{O}\right)(\bullet)$ and $\mathrm{DLI}\left(\mathrm{DMAI}+\mathrm{O}_{2}\right)(\mathrm{O})$, and carbon atomic concentrations measured from XPS $(\triangle)$. Note that the reported $C$ concentration is for $\mathrm{C}$ atoms bonded to $\mathrm{Al}$ only, excluding measured aliphatic $\mathrm{C}-\mathrm{C}$ and $\mathrm{C}-\mathrm{H}$ residues. ${ }^{17,18}$ For EPMA, each sample was measured at least 6 times in different locations to check the homogeneity of the composition. Samples measured with XPS were eroded by about $100 \mathrm{~nm}$ prior to the measurement.

ATI as a precursor (Fig. 1a) and below $300{ }^{\circ} \mathrm{C}$ using DMAI as a precursor in combination with $\mathrm{H}_{2} \mathrm{O}$ (Fig. 1b). Actually such films are more or less hydroxylated ${ }^{14,22}$ with an overall chemical composition of $\mathrm{Al}_{2} \mathrm{O}_{3-x}(\mathrm{OH})_{2 x}$ with $x$ between 0 and 1. Furthermore, $\mathrm{O} / \mathrm{Al}$ ratios below 1.5 were observed for films processed above $500{ }^{\circ} \mathrm{C}$ from DLI DMAI in combination with $\mathrm{O}_{2}$. This composition results from the incorporation of carbidic carbon which probably originates from the reaction of cyclohexane with the growing alumina film and/or from the incomplete decomposition of DMAI (Fig. S2, ESI $\dagger$ ). Thus these films may be seen either as mixtures of aluminum oxide and aluminum carbide or non-stoichiometric aluminum oxycarbides having an overall chemical composition $\mathrm{Al}_{2} \mathrm{O}_{3-2 x} \mathrm{C}_{x}$ with $x$ between 0 and $3 / 2$. Although less frequently investigated than aluminum oxides, hydroxides $\left(\mathrm{Al}(\mathrm{OH})_{3}\right)$ and oxyhydroxides $(\mathrm{AlO}(\mathrm{OH}))$, aluminum oxycarbides present significant scientific and technological 
interests related to their chemical as well as functional, namely refractory and abrasive, properties (ref. 23 and references therein).

The present paper discusses the structure on the atomic scale of amorphous aluminum oxide, oxyhydroxides (fully or partially hydroxylated) and carbidic C containing films prepared by DLI-CVD from ATI and DMAI precursors, and probed by very high field ${ }^{27} \mathrm{Al}$ SSNMR. In order to further understand the chemical nature of the carbidic C containing films, Density Functional Theory (DFT) computations allowing the calculation of the ${ }^{27} \mathrm{Al} \mathrm{NMR}$ spectra are performed on crystalline $\mathrm{Al}_{4} \mathrm{C}_{3}$ and $\mathrm{Al}_{4} \mathrm{O}_{4} \mathrm{C}$. Both compounds are of interest because they are composed of tetrahedral aluminum environments, i.e. $\mathrm{AlC}_{4}$ and $\mathrm{AlO}_{3} \mathrm{C}$ units for $\mathrm{Al}_{4} \mathrm{C}_{3}$ and $\mathrm{Al}_{4} \mathrm{O}_{4} \mathrm{C}$, respectively. Therefore they could provide valuable insights into the possible atomic configurations of carbon in the films.

\section{Materials and methods}

\section{Sample preparation}

Deposition experiments were performed in a custom-made, horizontal, hot-wall CVD reactor described in previous works. ${ }^{17-20}$ Films were grown on either $50 \mu \mathrm{m}$ (University wafer) or $100 \mu \mathrm{m}$ thick (Sil'tronix), (100) oriented silicon wafers. Using thinner Si substrates increases the amount of alumina material in the NMR probe, which reduces the measurement time and/or increases the signal to noise ratio. Three DLI CVD processes were investigated using:

- DLI of ATI between $300{ }^{\circ} \mathrm{C}$ and $560{ }^{\circ} \mathrm{C}$.

- DLI of DMAI with $\mathrm{H}_{2} \mathrm{O}$ as an additional oxygen source, from $150{ }^{\circ} \mathrm{C}$ to $450{ }^{\circ} \mathrm{C}$.

- DLI of DMAI with $\mathrm{O}_{2}$ as an additional oxygen source, from $500{ }^{\circ} \mathrm{C}$ to $700{ }^{\circ} \mathrm{C}$.

These three processes will be named hereafter as "ATI", "(DMAI $\left.+\mathrm{H}_{2} \mathrm{O}\right)$ ") and "(DMAI $\left.+\mathrm{O}_{2}\right)$ ", respectively. In view of their injection in the process chamber, both ATI and DMAI are dissolved in anhydrous cyclohexane. ${ }^{19,20,24}$ For DMAI, the O/Al ratio is equal to $1(\mathrm{O} / \mathrm{Al}=3$ for $\mathrm{ATI})$ and for this reason an additional oxygen source $\left(\mathrm{H}_{2} \mathrm{O}\right.$ or $\left.\mathrm{O}_{2}\right)$ is required for the CVD of alumina from this precursor $\left(\mathrm{O} / \mathrm{Al}=1.5\right.$ in alumina). ${ }^{17,18}$ The experimental protocols used for each process are presented in detail in the corresponding references and the process conditions are summarized in Table 1 . The total number of films which have been characterized by SSNMR corresponds to 11 films processed from ATI and 10 films processed from DMAI.

\section{Solid-state NMR characterization}

All solid-state ${ }^{27} \mathrm{Al}$ NMR experiments were carried out on a Bruker AVANCE III spectrometer operating at a magnetic field of $20.0 \mathrm{~T}$ (corresponding to the ${ }^{27} \mathrm{Al}$ frequency of $221.5 \mathrm{MHz}$ ) with a $2.5 \mathrm{~mm}$ MAS probe head. All spectra were referenced with respect to a $1 \mathrm{M}$ solution of $\mathrm{Al}\left(\mathrm{NO}_{3}\right)_{3}$. The ${ }^{27} \mathrm{Al}$ onedimensional (1D) MAS spectra were recorded with a spinning frequency of $35 \mathrm{kHz}$ and were simulated using the Dmfit software. $^{25}$ The excitation pulse length was of $0.4 \mu \mathrm{s}$, i.e. a flip angle less than $\pi / 18$ to ensure a quantitative $1 \mathrm{D}$ spectrum $^{26}$ (radio-frequency field $\nu_{\mathrm{RF}}=35 \mathrm{kHz}$ ). The recycle delay was $20 \mathrm{~ms}$ (spin-lattice relaxation time $T_{1}$ of $c a .200 \mathrm{~ms}$, estimated with a saturation-recovery experiment on the most sensitive sample) and the number of transients was between $260 \mathrm{k}$ and $1000 \mathrm{k}$ depending on the film thickness. The ${ }^{27} \mathrm{Al}$ signal from the probe background was acquired under the same experimental conditions using the empty rotor. After normalization according to the number of transients, it was subtracted from the baseline-corrected spectra.

The two-dimensional (2D) z-filtered multiple-quantum ${ }^{27} \mathrm{Al}$ MQMAS experiments ${ }^{27,28}$ were performed with a spinning frequency of $30 \mathrm{kHz}$, with triple-quantum (3Q) excitation and reconversion pulse lengths of $2.0 \mu \mathrm{s}$ and $0.9 \mu \mathrm{s}$, respectively $\left(\nu_{\mathrm{RF}}=128 \mathrm{kHz}\right)$. The $\mathrm{z}$-filter duration was $3.3 \mathrm{~ms}$ and the selective pulse length of the central transition was $7.5 \mu \mathrm{s}\left(\nu_{\mathrm{RF}}=10 \mathrm{kHz}\right)$. Acquisition in the indirect dimension was synchronized with the spinning frequency ${ }^{29}$ and twelve to fourteen $t_{1}$ increments of $33.3 \mu$ s were collected with a recycle delay of $200 \mathrm{~ms}$ and a number of transients varying between $40 \mathrm{k}$ and $64 \mathrm{k}$. The $3 \mathrm{QMAS}$ experiments lasted for about 3-4 days per sample.

\section{Computational work}

First principles calculations with periodic boundary conditions were performed using the CASTEP $\operatorname{code}^{30,31}$ which employs the plane-wave pseudopotential formalism of DFT. The electron correlation effects were modeled using the Perdew-BurkeErnzerhof (PBE) generalized gradient approximation (GGA). ${ }^{32}$ For geometry optimizations, we employed a planewave cutoff energy of $390 \mathrm{eV}$, the default "on the fly" "ultrasoft" pseudopotentials $^{33}$ of Material Studio (ver. 5.5) and convergence thresholds were set to $5 \times 10^{-7} \mathrm{eV}$ atom $^{-1}$ for the total energy, $5 \times 10^{-6} \mathrm{eV}^{-1}$ for the maximum ionic force and $5 \times 10^{-4} \AA$ for the maximum ionic displacement. A Monkhorst-Pack grid of $7 \times 7 \times 7$ (a separation of $0.05 \AA^{-1}$ ) was used to sample the Brillouin zone. ${ }^{34}$ Unit cell parameters from the model structures reported by Gesing et al. for aluminum carbide $\mathrm{Al}_{4} \mathrm{C}_{3}{ }^{35}$ and Jeffrey et al. for aluminum tetroxycarbide $\mathrm{Al}_{4} \mathrm{O}_{4} \mathrm{C}^{36}$ were used and kept fixed during the optimizations. The NMR calculations were performed using the Gauge Including Projector Augmented Wave (GIPAW) approach using the same settings as that used for geometry optimization. ${ }^{37,38}$ The calculated isotropic shieldings $\sigma_{\text {iso }}$ were converted into isotropic chemical shift $\delta_{\text {iso }}$ using correlations established in CEMHTI (Orléans, France) on

Table 1 Process conditions for the CVD of amorphous alumina films from ATI and DMAI precursors

\begin{tabular}{llllll}
\hline Temperature $\left({ }^{\circ} \mathrm{C}\right)$ & Process & Precursor & Reactive gas flow $(\mathrm{sccm})$ & Injection mixing $\mathrm{N}_{2}$ flow $(\mathrm{sccm})$ & Dilution $\mathrm{N}_{2}$ flow (sccm) \\
\hline $300-560$ & DLI CVD & ATI & n/a & 300 & 300 \\
$150-450$ & DLI CVD & DMAI & $\mathrm{H}_{2} \mathrm{O}, 120$ & 300 & 300 \\
$500-700$ & DLI CVD & DMAI & $\mathrm{O}_{2}, 50$ & 400 & 400
\end{tabular}


well-defined crystalline model compounds according to $\delta_{\text {iso }}=$ $-0.977 \times{ }^{\text {calc }} \sigma_{\text {iso }}+541.9 .^{39}$

\section{Results and discussion}

The local structure of the amorphous $\mathrm{Al}_{2} \mathrm{O}_{3}$ thin films was probed experimentally using very high magnetic field solid-state ${ }^{27} \mathrm{Al}$ MAS NMR $(20 \mathrm{~T})$ which allows identifying and quantifying the polyhedral aluminum coordination in terms of proportions (at\%) and the degree of local disorder (polyhedron distortions). Fig. 2-4 present experimental and reconstructed ${ }^{27} \mathrm{Al}$ MAS NMR spectra of alumina films prepared from ATI, (DMAI $\left.+\mathrm{H}_{2} \mathrm{O}\right)$, and (DMAI $+\mathrm{O}_{2}$ ), respectively. Fitting of the NMR spectra was performed using the “Czjzek model” (Gaussian isotropic model) which provides the averaged isotropic chemical shift $\left(\overline{\delta_{\text {iso }}}\right)$, the chemical shift distribution $(\triangle \mathrm{CS})$, and the standard deviation of the EFG tensor elements' distribution $\left(\overline{C_{\mathrm{Q}}}\right) \cdot{ }^{40,41} \mathrm{For}{ }^{27} \mathrm{Al}$ in aluminates, $\overline{\delta_{\text {iso }}}$ is mainly governed by chemical modifications of the second coordination sphere, while $\Delta \mathrm{CS}$ and $\overline{C_{\mathrm{Q}}}$ measure the distortion (bond lengths and/or angles) of the coordination polyhedra. ${ }^{42}$ Because there are
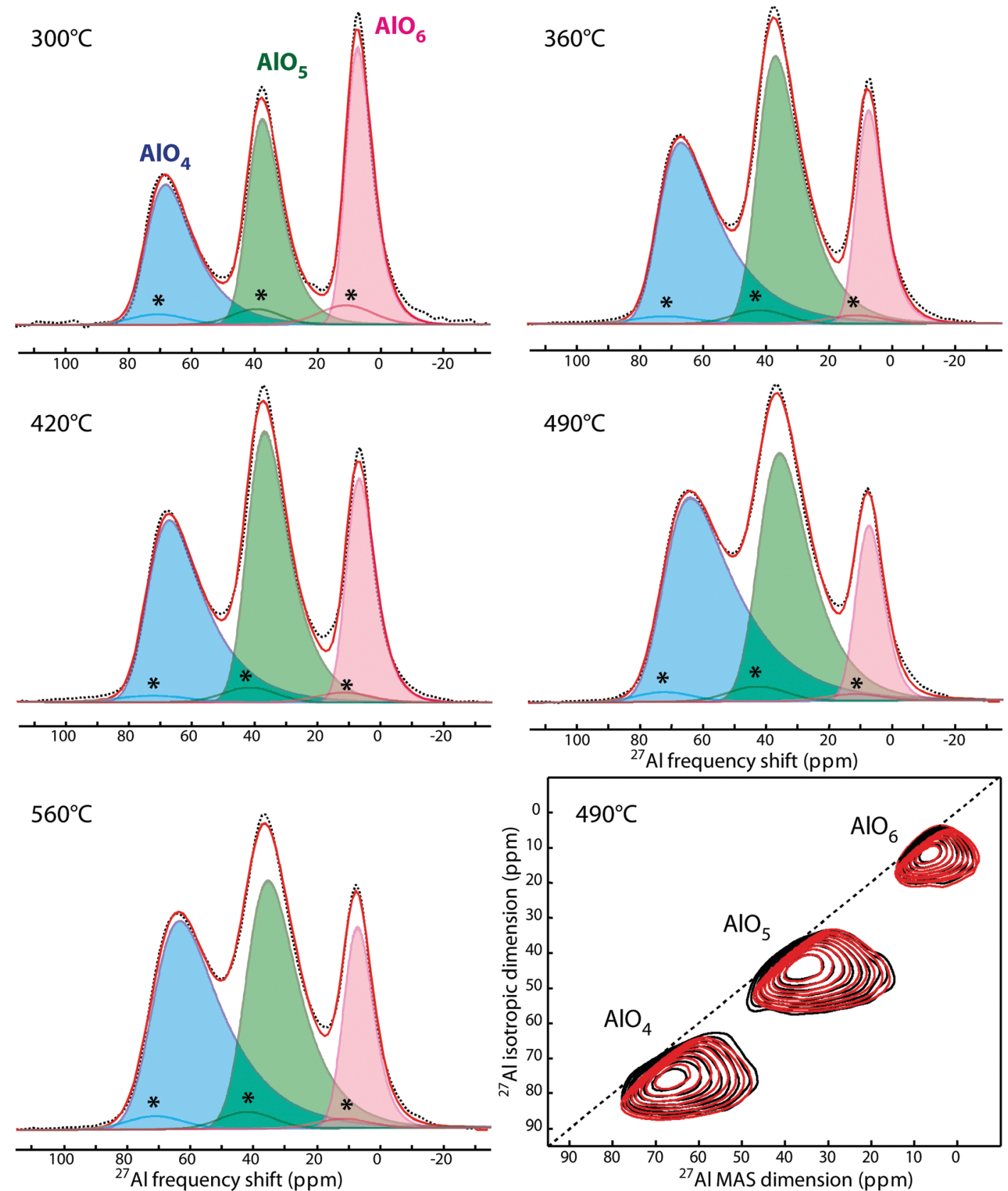

Fig. 2 Experimental (dashed black lines) and reconstructed (full red lines) ${ }^{27} \mathrm{Al}$ MAS NMR spectra of alumina films prepared by DLI ATI in $\mathrm{N}_{2}$ from 300 to $560{ }^{\circ} \mathrm{C}$. The $2 \mathrm{D} 3 \mathrm{QMAS}$ spectrum of the $490^{\circ} \mathrm{C}$ sample is shown as an example. The $\mathrm{AlO}_{4}$ (blue), $\mathrm{AlO}_{5}$ (green) and $\mathrm{AlO}_{6}$ (pink) coordination environments are fitted along with their respective MAS-related sidebands $\left(^{*}\right)$ which correspond to the bands $n=0$ of the external transitions. 

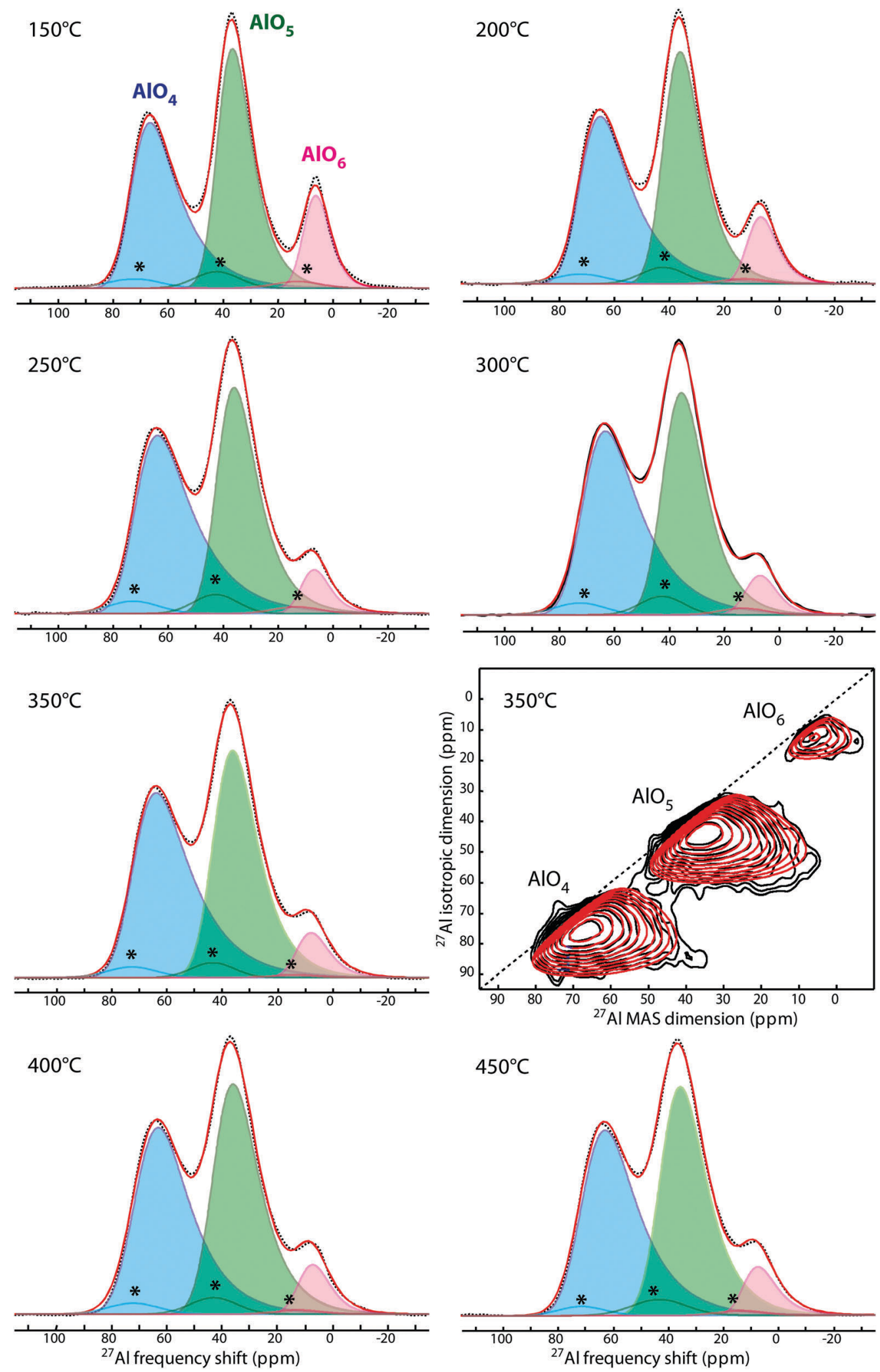

Fig. 3 Experimental (dashed black lines) and reconstructed (full red lines) ${ }^{27} \mathrm{Al}$ MAS NMR spectra of alumina films prepared by DMAI with $\mathrm{H}_{2} \mathrm{O}$ from 150 to $450{ }^{\circ} \mathrm{C}$. The $2 \mathrm{D} 3 \mathrm{QMAS}$ of the $350^{\circ} \mathrm{C}$ sample is shown as an example. The $\mathrm{AlO}_{4}$ (blue), $\mathrm{AlO}_{5}$ (green) and $\mathrm{AlO}_{6}$ (pink) coordination environments are fitted along with their respective MAS-related sidebands (*) which correspond to the bands $n=0$ of the external transitions. 

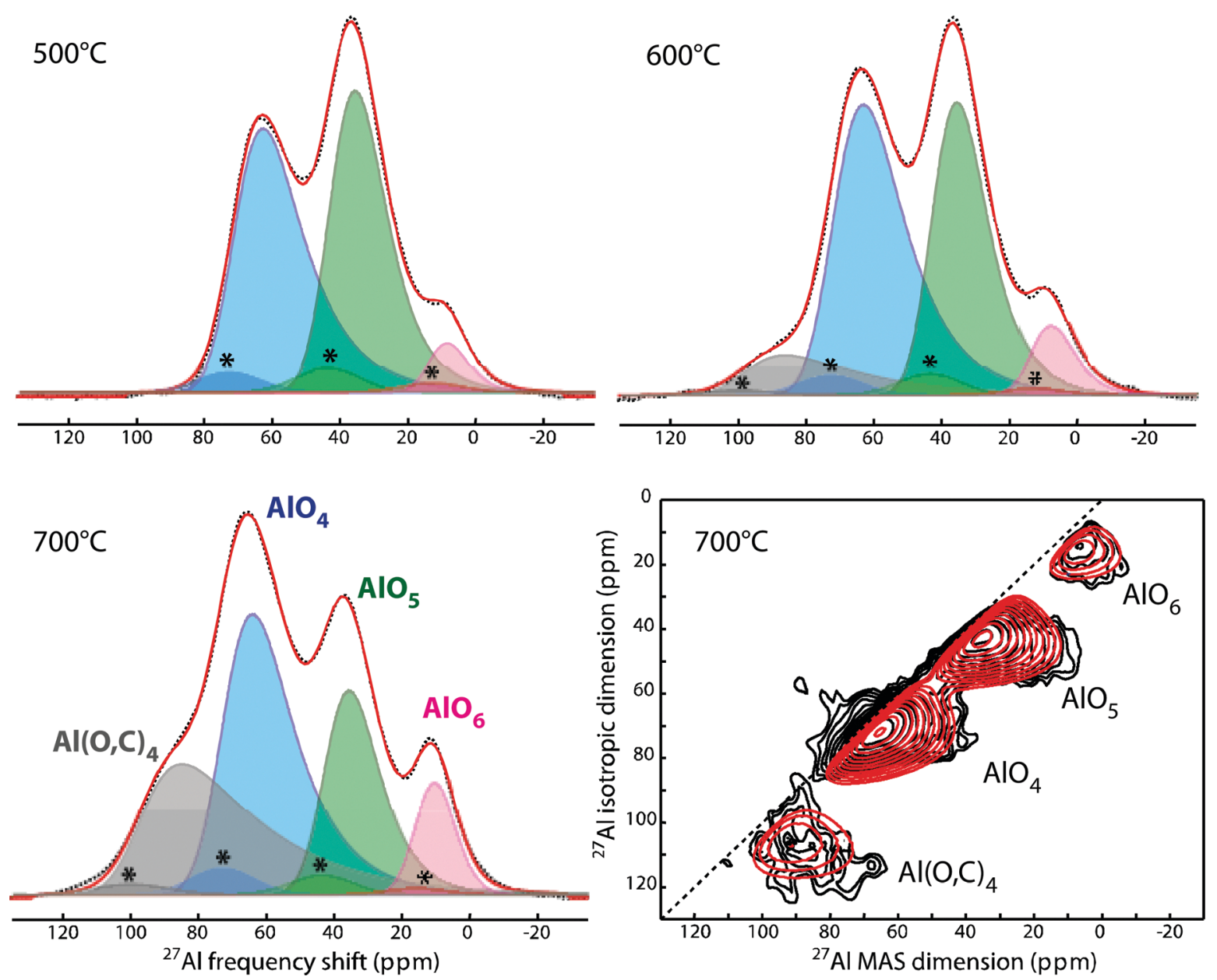

Fig. 4 Experimental (dashed black lines) and reconstructed (full red lines) ${ }^{27} \mathrm{Al}$ MAS NMR spectra of alumina films prepared by (DMAI + $\mathrm{O}_{2}$ ) from 500 to $700{ }^{\circ} \mathrm{C}$. The $2 \mathrm{D} 3 \mathrm{QMAS}$ for $700{ }^{\circ} \mathrm{C}$ is shown as an example. The $\mathrm{AlO}_{4}$ (blue), $\mathrm{AlO}_{5}$ (green), $\mathrm{AlO}_{6}$ (pink) and $\mathrm{Al}(\mathrm{O}, \mathrm{C})_{4}$ (grey) coordination environments are fitted with their respective MAS-related sidebands $(*)$ which correspond to the bands $n=0$ of the external transitions.

too many parameters $\left(\overline{\delta_{\text {iso }}}, \Delta \mathrm{CS}, \overline{C_{\mathrm{Q}}}\right.$, amplitude) to optimize for a relevant reconstruction of the $1 \mathrm{D}$ quantitative spectrum, the 3 QMAS ${ }^{27} \mathrm{Al}$ spectrum is primarily fitted in order to extract properly the chemical shift distribution $(\Delta \mathrm{CS})$ of each $\mathrm{Al}$ environment. The 1D quantitative spectrum is then fitted by fixing $\Delta$ CS.

The one dimensional ${ }^{27} \mathrm{Al}$ MAS NMR spectra consist of 3 or 4 overlapping broad lines each corresponding to a specific $\mathrm{Al}$ coordination, ${ }^{12-15}$ which are characteristic of amorphous alumina-containing materials. ${ }^{14}$ The spectral reconstructions evidence $\mathrm{AlO}_{4}, \mathrm{AlO}_{5}$ and $\mathrm{AlO}_{6}$ coordination units in all materials, with no significant differences among their respective $\overline{\delta_{\text {iso }}}$ values. This observation indicates that the second coordination shell, expected to be composed of $\mathrm{Al}$ atoms, is essentially the same for all materials. Furthermore an additional broad line centered at around $90 \mathrm{ppm}$ is detected for the films processed from (DMAI + $\mathrm{O}_{2}$ ) at $600{ }^{\circ} \mathrm{C}$ and $700{ }^{\circ} \mathrm{C}$ (Fig. 4), which suggests the presence of a carbon containing aluminum environment (vide infra).

\section{Influence of the CVD process}

Fig. 5 represents the proportions of 4-, 5-, 6-fold coordinated aluminum units and the distribution of chemical shifts for various amorphous films as a function of $T_{\mathrm{d}}$. The results obtained in a former work on films prepared from evaporated $\mathrm{ATI}^{14}$ are inserted as reference (Fig. 5e and f). As previously mentioned, the crystalline alumina polymorphs (as well as aluminum hydroxides and oxyhydroxides) mainly consist of octahedral $\left(\mathrm{AlO}_{6}\right)$ units. Conversely, it was observed that the proportion of $\mathrm{AlO}_{6}$ units was strikingly low for amorphous alumina. ${ }^{12-15}$ Here again the 6-fold coordinated aluminum is rarely the major building unit, and the films exhibit $\mathrm{AlO}_{5}$ proportions of more than 40 at $\%$.

Nevertheless, the films processed from DLI ATI (Fig. 5a) show higher proportions of $\mathrm{AlO}_{6}$ units than those processed from DLI DMAI (Fig. 5c) or from evaporated ATI (Fig. 5e) ${ }^{14}$ The proportion of $\mathrm{AlO}_{6}$ does not decrease lower than $c a .15$ at\%, mainly at the benefit of $\mathrm{AlO}_{4}$, the content in $\mathrm{AlO}_{5}$ remaining nearly stable at $c a .40$ at\% (Fig. 5a). Moreover the chemical shift distributions ( $\triangle \mathrm{CS}$ ) are lower for the DLI ATI films (Fig. $5 \mathrm{~b}$ ) compared to others (Fig. 5d and f) denoting a lower local disorder. The lower disorder and smaller (higher) concentration of $\mathrm{AlO}_{4}\left(\mathrm{AlO}_{6}\right)$ can be correlated with the particular microstructure of the DLI ATI films showing a columnar growth, which can be seen as a consequence of local structure ordering (Fig. S1, ESI $†$ ). 

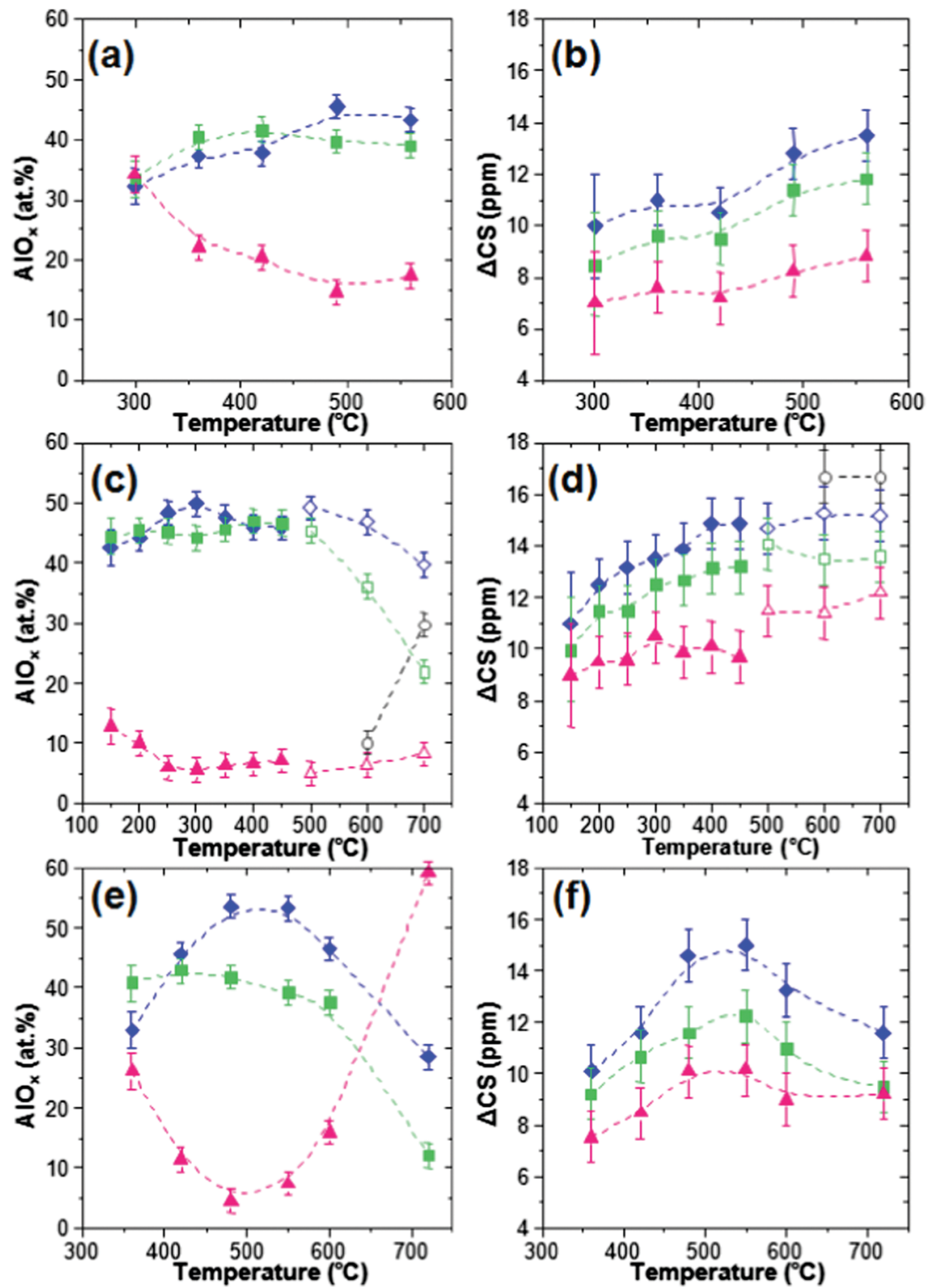

Fig. 5 Distribution of the $\mathrm{AlO}_{4}$ (blue diamonds), $\mathrm{AlO}_{5}$ (green squares), $\mathrm{AlO}_{6}$ (pink triangles), and $\mathrm{Al}(\mathrm{O}, \mathrm{C})_{4}$ (black circles) concentrations (at\%) and chemical shift distributions $(\triangle C S)$ probed in the alumina films prepared using (a and b) DLI ATI in $\mathrm{N}_{2}$ from 300 to $560{ }^{\circ} \mathrm{C}$, (c and d) (DMAI + $\mathrm{H}_{2} \mathrm{O}$ ) from 150 to $450{ }^{\circ} \mathrm{C}$ and $\mathrm{O}_{2}$ from 500 to $700{ }^{\circ} \mathrm{C}$, and (e and f) evaporated ATI from 360 to $720{ }^{\circ} \mathrm{C}\left(+\mathrm{O}_{2}\right)$. The relative concentrations are derived from the specific areas of the fitted 1D spectra.

By contrast, the films processed from DMAI show remarkably low proportions of $\mathrm{AlO}_{6}$ units that has never been observed for such a wide range of temperature. Indeed the temperature window of $\mathrm{AlO}_{6}$ proportion below 10 at $\%$ extends from $200{ }^{\circ} \mathrm{C}$ to $700{ }^{\circ} \mathrm{C}$ for DMAI (Fig. $5 \mathrm{c}$ ), and between ca. $440{ }^{\circ} \mathrm{C}$ and $560{ }^{\circ} \mathrm{C}$ only for evaporated ATI (Fig. 5e). For instance, the film processed from (DMAI $+\mathrm{H}_{2} \mathrm{O}$ ) at $300{ }^{\circ} \mathrm{C}$ is composed of 4-, 5- and 6-fold coordinated aluminum with proportions of 50 at $\%, 44$ at $\%$ and 6 at\%, respectively. It is worth noting that a distribution with such a low level of $\mathrm{AlO}_{6}$ units and for such a low temperature of synthesis has never been described for CVD processes. Moreover, higher values of $\Delta \mathrm{CS}$ are obtained for all the aluminum units for DMAI (Fig. 5d). In other words, the films processed from DMAI exhibit the most disordered atomic structure in our set of samples.

\section{The local structure according to the $\mathrm{O} / \mathrm{Al}$ ratio}

Amorphous oxide films. The elemental analyses pointed out that the CVD technique allows us to process amorphous films with $\mathrm{O} / \mathrm{Al}$ ratios different from the theoretical value for alumina (1.5). Actually stoichiometric alumina films are only obtained above $480^{\circ} \mathrm{C}$ for DLI ATI and evaporated ATI, and in the $300-500{ }^{\circ} \mathrm{C}$ temperature window for DMAI. The results clearly show the difference between both aluminum precursors in terms of processing temperature windows, obtained compositions and local order structures. They also highlight the remarkable feature 
of DMAI to process amorphous alumina films at low temperature. Moreover, very low proportions of $\mathrm{AlO}_{6}$ units are achieved in the alumina films. For DLI ATI and evaporated ATI, the minimum of $\mathrm{AlO}_{6}$ occurs at ca. $500{ }^{\circ} \mathrm{C}$, i.e. the lowest temperature to obtain near stoichiometric amorphous alumina. For DMAI, however, the proportion of $\mathrm{AlO}_{6}$ coordinated units remains quite stable from 250 to $600{ }^{\circ} \mathrm{C}$, considering the uncertainty of the quantification $\left(48 \pm 2 \%\right.$ for $\mathrm{AlO}_{4}, 46 \pm 1.5 \%$ for $\mathrm{AlO}_{5}, 6 \pm 1 \%$ for $\left.\mathrm{AlO}_{6}\right)$. Hence, it is clear that the deposition temperature is not the sole factor determining the local atomic structure. The actual surface reaction steps and kinetics influenced by, non-exhaustively, the precursorsolvent interactions, reactor pressure, molar fractions, (sub)species diffusivities, can play an important role in influencing the coordination of the atomic building units. Nevertheless, in all cases, the distribution of the chemical shift increases with $T_{\mathrm{d}}$ suggesting that the highest structural disorder is reached near $500{ }^{\circ} \mathrm{C}$, similar to the films processed from ATI.

Amorphous hydroxylated oxide films. For films with an $\mathrm{O} / \mathrm{Al}$ ratio larger than 1.5 , the ratio increases with decreasing temperature deposition. This phenomenon occurs below ca. $480{ }^{\circ} \mathrm{C}$ and below ca. $300{ }^{\circ} \mathrm{C}$ for films processed from ATI (Fig. 1a) and from DMAI (Fig. 1b), respectively. As previously demonstrated, this observation corresponds to the partial hydroxylation of the films, which is promoted when the deposition temperature decreases. ${ }^{14,22}$ In terms of the local atomic structure, the proportion of $\mathrm{AlO}_{6}$ (resp. $\mathrm{AlO}_{4}$ ) units increases (resp. decreases) while the $\mathrm{O} / \mathrm{Al}$ ratio increases with decreasing $T_{\mathrm{d}}$ independently of the CVD process and the involved precursor. Actually the increasing proportion of $\mathrm{AlO}_{6}$ units results from the fact that the hydroxyl groups are preferentially bonded to the 6-fold coordinated Al. ${ }^{14,43,44}$ It is worth noting that the films processed from DMAI are less hydroxylated than the other ones concomitantly with the presence of exceptionally low proportions of $\mathrm{AlO}_{6}$ units (6-13 at\%). This result suggests the existence of a direct correlation between the amount of hydroxyl groups and the proportion of $\mathrm{AlO}_{6}$ units.

Amorphous carbidic C containing films. Carbidic carboncontaining films characterized by an $\mathrm{O} / \mathrm{Al}$ ratio smaller than 1.5 are only observed for the films processed from (DMAI $+\mathrm{O}_{2}$ ) and for temperatures higher than $500{ }^{\circ} \mathrm{C}$. This corresponds to the XPS detection of carbon inside the films (Fig. 1b and Fig. S2, ESI $\dagger$ ). The ${ }^{27} \mathrm{Al}$ spectra at $600{ }^{\circ} \mathrm{C}$ and $700{ }^{\circ} \mathrm{C}$ reveal indeed the presence of an additional broad line located above $80 \mathrm{ppm}$ (Fig. 4), which is a chemical shift more positive than the typical positions of $\mathrm{AlO}_{4}$ units found in pure alumina. This indicates the formation of a tetrahedral environment including an element less electronegative than $\mathrm{O}$ like C. ${ }^{27} \mathrm{Al}$ SSNMR on aluminum carbide $\left(\mathrm{Al}_{4} \mathrm{C}_{3}\right)$ has been investigated by Bräuniger et al. ${ }^{45}$ and the corresponding experimental chemical shifts as well as quadrupolar coupling constants are in good agreement with our spectrum reconstruction $\left(\overline{\delta_{\text {iso }}}=98.5 \mathrm{ppm}, \overline{C_{\mathrm{Q}}}=14 \mathrm{MHz}\right)$. In the present work, the carbon content does not exceed 7 at\% ( $v s$. 42.8 at\% in $\mathrm{Al}_{4} \mathrm{C}_{3}$ ) which suggests that the first coordination sphere of aluminum may not only be filled with carbon atoms, but also with oxygen ones. Three crystalline aluminum oxycarbides have been described in the literature - $\mathrm{Al}_{2} \mathrm{OC},{ }^{23} \mathrm{Al}_{4} \mathrm{O}_{4} \mathrm{C}$, and
$\mathrm{Al}_{6} \mathrm{O}_{7} \mathrm{C}^{46}$ - which are composed of $\mathrm{Al}(\mathrm{O}, \mathrm{C})_{4}$ tetrahedra. Because $\mathrm{O}$ and $\mathrm{C}$ share the same crystallographic sites in $\mathrm{Al}_{2} \mathrm{OC}$ and $\mathrm{Al}_{6} \mathrm{O}_{7} \mathrm{C}$ (mixed occupancy), DFT calculations were only performed on $\mathrm{Al}_{4} \mathrm{C}_{3}$ and $\mathrm{Al}_{4} \mathrm{O}_{4} \mathrm{C}$. Both compounds are composed of two $\left(\mathrm{Al}_{4} \mathrm{C}_{3}\right)$ and three $\left(\mathrm{Al}_{4} \mathrm{O}_{4} \mathrm{C}\right)$ tetrahedral aluminum environments (Fig. S3, ESI $\dagger$ ). Their calculated isotropic chemical shifts $\left(\delta_{\text {iso }}\right)$ are 98.5 and $112 \mathrm{ppm}\left(\mathrm{Al}_{4} \mathrm{C}_{3}\right)$, and 114.2, 101.5 and $97.5 \mathrm{ppm}\left(\mathrm{Al}_{4} \mathrm{O}_{4} \mathrm{C}\right)$ with respective quadrupolar coupling constants of 14.7 and $16.3 \mathrm{MHz}$ $\left(\mathrm{Al}_{4} \mathrm{C}_{3}\right)$, and $18.8,10.6$ and $11.1 \mathrm{MHz}\left(\mathrm{Al}_{4} \mathrm{O}_{4} \mathrm{C}\right)$. In order to compare the additional contribution in the ${ }^{27} \mathrm{Al}$ NMR quantitative spectrum of carbidic $\mathrm{C}$ containing films with the calculated DFT-based NMR spectra of $\mathrm{Al}_{4} \mathrm{C}_{3}$ and $\mathrm{Al}_{4} \mathrm{O}_{4} \mathrm{C}$, an artificial Lorentzian line broadening was applied on the spectra of both crystalline compounds such that it reintroduces a kind of chemical shift distribution (Fig. 6). The positions of the obtained broad lines are very close to the one measured for the additional environment observed in Fig. 5. It can also be noticed that a better match is found with the computed $\mathrm{Al}_{4} \mathrm{O}_{4} \mathrm{C}$, indicating that the new environment corresponds more probably to $\mathrm{Al}(\mathrm{O}, \mathrm{C})_{4}$ units. Furthermore, by combining the results from the carbon content (XPS) and the proportion of the

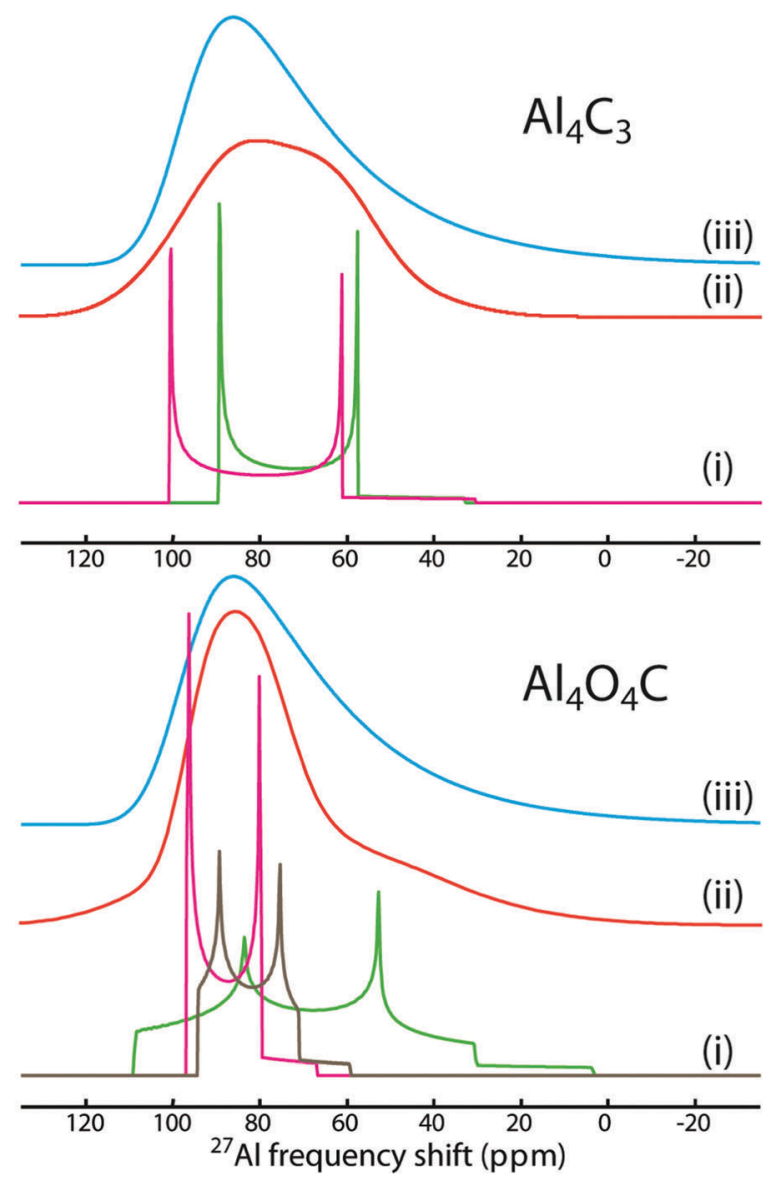

Fig. 6 (i) ${ }^{27} \mathrm{Al}$ NMR spectra of the different crystallographic sites of aluminum for $\mathrm{Al}_{4} \mathrm{C}_{3}$ (2 sites) and $\mathrm{Al}_{4} \mathrm{O}_{4} \mathrm{C}$ (3 sites) simulated with the NMR parameters obtained from DFT calculations. (ii) The ${ }^{27} \mathrm{Al}$ NMR spectrum resulting from the contribution of all crystallographic sites for $\mathrm{Al}_{4} \mathrm{C}_{3}$ and $\mathrm{Al}_{4} \mathrm{O}_{4} \mathrm{C}$ and assuming a Gaussian line broadening of $800 \mathrm{~Hz}$. (iii) Simulated spectrum corresponding to the $\mathrm{Al}(\mathrm{O}, \mathrm{C})_{4}$ environment obtained in the quantitative reconstruction (Czjzek model). 
$\mathrm{Al}(\mathrm{O}, \mathrm{C})_{4}$ unit (SSNMR) for the films at $600{ }^{\circ} \mathrm{C}$ and $700{ }^{\circ} \mathrm{C}$, it was possible to estimate an averaged content of $\mathrm{C}$ and $\mathrm{O}$ in the tetrahedron $\mathrm{AlO}_{4-x} \mathrm{C}_{x}$ such that $x=0.97 \pm 0.49$ for $T_{\mathrm{d}}=600{ }^{\circ} \mathrm{C}$ and $x=0.45 \pm 0.18$ for $T_{\mathrm{d}}=700{ }^{\circ} \mathrm{C}$. Although there is an error of ca. $50 \%$, this estimation supports the fact that aluminum is not coordinated to carbon only.

In terms of quantitative analysis, the proportion of $\mathrm{Al}(\mathrm{O}, \mathrm{C})_{4}$ units increases with the temperature of deposition. These oxycarbide units (up to 30 at $\%$ at $700{ }^{\circ} \mathrm{C}$ ) are formed at the expense of the $\mathrm{AlO}_{4}$ and $\mathrm{AlO}_{5}$ units $\left(\mathrm{AlO}_{6}\right.$ slightly increases with $T_{\mathrm{d}}$ ), evidencing that the $\mathrm{O} / \mathrm{C}$ substitution occurs preferentially on these low-coordinated aluminum species. The chemical shift distribution reaches the highest values ever observed for such amorphous films, and remains stable over the $500-700{ }^{\circ} \mathrm{C}$ temperature range. This points to a greater topological disorder induced by the $\mathrm{C} / \mathrm{O}$ chemical substitution (i.e. chemical disorder) in those films with respect to those obtained from evaporated ATI in the same temperature window. Indeed the ATI-based films start to crystallize into $\gamma$-alumina, which indicates that the carbidization stabilizes the amorphous structure and prevents from crystallization.

\section{Conclusions}

This work reports an unprecedented overview of the influence of the MOCVD processing conditions (involving the chemical system - ATI, DMAI; the precursor transport technology evaporation or DLI; deposition temperature) on the atomic scale structure of amorphous alumina films. Using very high field ${ }^{27} \mathrm{Al}$ solid-state NMR $(20 \mathrm{~T})$, it is shown that all the amorphous films (21 samples) present a high degree of local disorder which always consists of 4-, 5- and 6-fold coordinated aluminum units with various proportions notably depending on the temperature deposition. As observed by previous studies, ${ }^{12-16}$ the common characteristic of these amorphous materials is the very low proportion of $\mathrm{AlO}_{6}$ units, which are generally the main building units for all crystallized aluminum oxides, hydroxides, and oxyhydroxides. Conversely the cumulative proportions of $\mathrm{AlO}_{5}$ and $\mathrm{AlO}_{4}$ units can represent up to 85 at $\%$ at $450-500{ }^{\circ} \mathrm{C}, 94$ at $\%$ at $300{ }^{\circ} \mathrm{C}$ and 95 at $\%$ at $500{ }^{\circ} \mathrm{C}$ for films processed from ATI, (DMAI $+\mathrm{H}_{2} \mathrm{O}$ ) and (DMAI $+\mathrm{O}_{2}$ ), respectively. It is worth noting that MOCVD processing using DMAI offers the largest panel of chemical compositions for such amorphous films (oxyhydroxide, oxide, oxycarbide) by varying the deposition temperature $\left(150-700{ }^{\circ} \mathrm{C}\right)$, notably.

The combination of elemental analyses (EPMA and XPS) and SSNMR reveals that:

- The hydroxylation of the film occurring at low temperature $\left(T_{\mathrm{d}}<480{ }^{\circ} \mathrm{C}\right.$ for ATI, $T_{\mathrm{d}}<300{ }^{\circ} \mathrm{C}$ for DMAI) involves an increase of the proportion of $\mathrm{AlO}_{6}$ units which is caused by the preference of $\mathrm{OH}$ groups to bond to $\mathrm{Al}$ in octahedral configuration.

- The carbidization of the films processed from (DMAI $\left.+\mathrm{O}_{2}\right)$ leads to the substitution of oxygen by carbon to form new $\mathrm{Al}(\mathrm{O}, \mathrm{C})_{4}$ units, and hence the formation of highly disordered amorphous oxycarbide materials even at $T_{\mathrm{d}}>500{ }^{\circ} \mathrm{C}$.
Finally, the present investigation dealing with the process/ atomic scale structure correlation in CVD amorphous alumina films paves the way to the processing of value-added coating materials whose characteristics (chemical resistance, temperature stability...) can be monitored by appropriately tuning the CVD process conditions in such a way that they match targeted specifications.

\section{Acknowledgements}

Philippe de Parseval (R. Castaing MicroCharacterization Center), Yannick Thébault and Jérôme Esvan (CIRIMAT) are gratefully acknowledged for conducting EPMA, SEM and XPS measurements, respectively. L. B., A. N. G. and C. V. thankfully acknowledge the STAE-RTRA Foundation (Toulouse) for financial support under the RTRA-STAE/2014/P/VIMA/12 project grant. L. B., A. N. G. and C. V. are indebted to the IR-RMN-THC FR3050 CNRS for the machine time access and the financial support of the NMR experiments. L. B. and V. S.-K. equally contributed to this work.

\section{References}

1 H. Klauk, Nat. Mater., 2009, 8, 853-854.

2 I. Lahiri, S.-M. Oh, J. Y. Hwang, C. Kang, M. Choi, H. Jeon, R. Banerjee, Y.-K. Sun and W. Choi, J. Mater. Chem., 2011, 21, 13621-13626.

3 T. Q. Nguyen, A. K. Thapa, V. K. Vendra, J. B. Jasinski, G. U. Sumanasekeraac and M. K. Sunkara, RSC Adv., 2014, 4, 3312-3317.

4 F. C. Carreri, R. Bandorf, H. Gerdes, M. Vergohl and G. Brauer, Surf. Coat. Technol., 2016, 290, 82-86.

5 A.-M. Lazar, W. P. Yespica, S. Marcelin, N. Pébère, D. Samélor, C. Tendero and C. Vahlas, Corros. Sci., 2014, 81, 125-131.

6 S. Nath, I. Manna, S. K. Ray and J. D. Majumdar, Ceram. Int., 2016, 42, 7060-7071.

7 L. Baggetto, C. Charvillat, Y. Thébault, J. Esvan, M. C. Lafont, E. Scheid, G. M. Veith and C. Vahlas, Phys. Status Solidi A, 2016, 213, 470-480.

8 A. C. M. Esther, N. Sridhara, S. V. Sebastian, P. Bera, C. Anandan, S. T. Aruna, D. Rangappa, A. K. Sharma and A. Dey, J. Mater. Sci.: Mater. Electron., 2015, 26, 9707-9716.

9 V. A. Dlugunovich, A. Y. Zhumar, S. N. Kurilkina and N. I. Mukhurov, J. Appl. Spectrosc., 2015, 82, 824-830.

10 B. Dudem, J. W. Leem, M. Choi and J. S. Yu, Appl. Phys. B: Lasers Opt., 2015, 118, 439-447.

11 Y. Balcaen, N. Radutoiu, J. Alexis, J. D. Béguin, L. Lacroix, D. Samelor and C. Vahlas, Surf. Coat. Technol., 2011, 206, 1684-1690.

12 S. K. Lee, S. B. Lee, S. Y. Park, Y. S. Yi and C. W. Ahn, Phys. Rev. Lett., 2009, 103, 095501.

13 S. K. Lee, S. Y. Park, Y. S. Yi and J. Moon, J. Phys. Chem. C, 2010, 114, 13890-13894.

14 V. Sarou-Kanian, A. N. Gleizes, P. Florian, D. Samelor, D. Massiot and C. Vahlas, J. Phys. Chem. C, 2013, 117, 21965-21971. 
15 S. K. Lee and C. W. Ahn, Sci. Rep., 2014, 4, 4200.

16 N. Kim, R. Bassiri, M. M. Fejer and J. F. Stebbins, J. NonCryst. Solids, 2014, 405, 1-6.

17 L. Baggetto, C. Charvillat, J. Esvan, Y. Thébault, D. Samélor, H. Vergnes, B. Caussat, A. Gleizes and C. Vahlas, Chem. Vap. Deposition, 2015, 21, 343-351.

18 L. Baggetto, J. Esvan, C. Charvillat, D. Samélor, H. Vergnes, B. Caussat, A. Gleizes and C. Vahlas, Phys. Status Solidi C, 2015, 12, 989-995.

19 P.-L. Etchepare, L. Baggetto, H. Vergnes, D. Samélor, D. Sadowski, B. Caussat and C. Vahlas, Phys. Status Solidi C, 2015, 12, 944-952.

20 P.-L. Etchepare, L. Baggetto, H. Vergnes, D. Samélor, D. Sadowski, B. Caussat and C. Vahlas, Adv. Mater. Interfaces, 2016, 3, 1600014.

21 D. Barreca, G. A. Battiston, R. Gerbasi and E. Tondello, J. Mater. Chem., 2000, 10, 2127-2130.

22 A. Gleizes, C. Vahlas, M. M. Sovar, D. Samélor and M. C. Lafont, Chem. Vap. Deposition, 2007, 13, 23-29.

23 Y. Nakashima, T. Shirai, C. Takai and M. Fuji, J. Ceram. Soc. Jpn., 2016, 124, 122-124.

24 P.-L. Etchepare, H. Vergnes, D. Samélor, D. Sadowski, C. Brasme, B. Caussat and C. Vahlas, Adv. Sci. Technol., 2014, 91, 117-122.

25 D. Massiot, F. Fayon, M. Capron, I. King, S. L. Calvé, B. Alonso, J. O. Durand, B. Bujoli, Z. Gan and G. Hoatson, Magn. Reson. Chem., 2002, 40, 70-76.

26 E. Lippmaa, A. Samoson and M. Mägi, J. Am. Chem. Soc., 1986, 108, 1730-1735.

27 J. P. Amoureux, C. Fernandez and S. Steuernagel, J. Magn. Reson., Ser. A, 1996, 123, 116-118.

28 A. Medek, J. S. Harwood and L. Frydman, J. Am. Chem. Soc., 1995, 117, 12779-12787.

29 D. Massiot, J. Magn. Reson., Ser. A, 1996, 122, 240-244.

30 M. D. Segall, P. J. D. Lindan, M. J. Probert, C. J. Pickard, P. J. Hasnip, S. J. Clark and M. C. Payne, J. Phys.: Condens. Matter, 2002, 14, 2717-2744.
31 S. J. Clark, M. D. Segall, C. J. Pickard, P. J. Hasnip, M. J. Probert, K. Refson and M. C. Payne, Z. Kristallogr., 2005, 220, 567-570.

32 J. P. Perdew, K. Burke and M. Ernzerhof, Phys. Rev. Lett., 1996, 77, 3865-3868.

33 D. Vanderbilt, Phys. Rev. B: Condens. Matter Mater. Phys., 1990, 41, 7892-7895.

34 H. J. Monkhorst and J. D. Pack, Phys. Rev. B: Solid State, 1976, 13, 5188-5192.

35 T. M. Gesing and W. Jeitschko, Z. Naturforsch., B: J. Chem. Sci., 1995, 50, 196-200.

36 G. A. Jeffrey and M. Slaughter, Acta Crystallogr., 1963, 16, 177-184.

37 C. J. Pickard and F. Mauri, Phys. Rev. B: Condens. Matter Mater. Phys., 2001, 63, 245101.

38 J. R. Yates, C. J. Pickard and F. Mauri, Phys. Rev. B: Condens. Matter Mater. Phys., 2007, 76, 024401.

39 S. Cadars, R. Guegan, M. N. Garaga, X. Bourrat, L. Le Forestier, F. Fayon, T. V. Huynh, T. Allier, Z. Nour and D. Massiot, Chem. Mater., 2012, 24, 4376-4389.

40 G. Czjzek, J. Fink, H. Schlmidt, J. M. D. Coey, J. P. Rebouillat and A. Lienard, Phys. Rev. B: Condens. Matter Mater. Phys., 1981, 23, 2513-2530.

41 G. Le Caër and R. A. Brand, J. Phys.: Condens. Matter, 1998, 10, 10715-10774.

42 P. Florian, E. Véron, T. Green, J. R. Yates and D. Massiot, Chem. Mater., 2012, 24, 4068-4079.

43 C. Pecharroman, I. Sobrados, I. E. Iglesias, T. GonzalezCarreno and J. Sanz, J. Phys. Chem. B, 1999, 103, 6160-6170.

44 T. Isobe, T. Watanabe, J. B. d'Espinose de la Caillerie, A. P. Legrand and D. Massiot, J. Colloid Interface Sci., 2003, 261, 320-324.

45 T. Bräuniger, C. V. Chandran, U. Wedig and M. Jansen, Z. Anorg. Allg. Chem., 2011, 637, 530-535.

46 T. Asaka, R. Kotani, T. Kudo, H. Yoshida and K. Fukuda, Inorg. Chem., 2013, 52, 2648-2653. 